\title{
PREVALENCE OF ASYMPTOMATIC BACTERIURIA AND ITS DISTRIBUTION BY SEX AND AGE GROUPS IN CHILDREN COMING FOR ROUTINE IMMUNIZATION IN DISTRICT PESHAWAR, PAKISTAN
}

\author{
Jahanzeb Khan Afridi', Rahida Karim', Hidayat Gul', Mukhtiar Ahmad Afridi', (D Muhammad Ibrahim² \\ Departments of Pediatrics, ${ }^{1}$ Khyber Girls Medical College, Peshawar, ${ }^{2}$ DHQT Hospital, D.I.Khan, Pakistan
}

\begin{abstract}
Background: Asymptomatic bacteriuria (ASB) in not an uncommon disease in children. It may lead to symptomatic infection and later on renal damage. The objectives of this study were to determine the prevalence of ASB and its distribution by sex and age groups in children coming for routine immunization in District Peshawar, Pakistan.

Material and methods: This cross-sectional study was conducted in Department of Pediatrics, Khyber Girls Medical College, Peshawar, Pakistan form March 2017 to August 2017. 146 children presenting for routine immunization were selected. Sex, age groups, age in years and presence of ASB were variables. Sex, age groups and presence of ASB were analyzed by count and percentage with $80 \% \mathrm{CL}$. Age in years was analyzed by mean, SD and range with $95 \% \mathrm{Cl}$.

Results: Out of 146 children, 65 (44.52\%) were males and $81(55.48 \%)$ females, and $51(34.93 \%)$ in age group $\leq 3$ years, $52(35.62 \%)$ in 3.0-6.50 years and $43(29.45 \%)$ in $6.51-10$ years. Mean age of sample was $4.82 \pm 2.81$ (09-9.50, range 8.60$)(95 \% \mathrm{Cl} 4.36-5.28)$ years. ASB was found in $16(10.96 \%)$ cases. Prevalence of ASB was higher $4.11 \%$ in boys than $6.856 \%$ girls. It was highest $6.85 \%$ in age group $3.0-6.50$ years, followed by $2.74 \%$ in $6.51-10$ years and $1.37 \%$ in age group $\leq 3.0$ years.

Conclusion: Asymptomatic Bacteriuria is quite common in our children. It is a significant health risk especially among females, and we suggest more studies to find out the underlying factors and follow up studies on its complications.

KEY WORDS: Bacteriuria, Asymptomatic Bacteriuria; Urine; Urine Culture; Immunization; Children; Prevalence; Distribution; Sex; Age Groups.

Cite as: Afridi JK, Karim R, Gul H, Afridi MA, Ibrahim M. Prevalence of asymptomatic bacteriuria and its distribution by sex and age groups in children coming for routine immunization in District Peshawar, Pakistan. Gomal J Med Sci 2021 Oct-Dec; 19(4):146-51. https://doi.org/10.46903/gjms/19.04.887
\end{abstract}

\section{INTRODUCTION}

1.1 Background: The presence of bacteria in correctly collected urine of a patient who has no signs or symptoms of a urinary tract infection is known as asymptomatic bacteriuria (ASB). In clinical practice, ASB is very common. Although it affects small infants and toddlers, it becomes more common

\section{Corresponding Author:}

Dr. Jahanzeb Khan Afridi

Assistant Professor, Department of Pediatrics

Khyber Girls Medical College

Peshawar, Pakistan.

E-mail: zarakbehram@yahoo.com

Date Submitted:

05-08-2020

Date Revised:

$17-07-2021$

Date Accepted: as they get older. Most patients with it will never develop symptomatic urinary tract infections, and it will have no negative effects. In an era where it's all about reducing excessive antibiotic use, the key clinical question is: which patients with ASB benefit from treatment? The majority of ASB patients do not benefit from therapy. However, there are a few exceptions. Patients undergoing urologic operations that are likely to cause mucosal bleeding, as well as those in the first three months after receiving a kidney transplant, should be screened for ASB., Urinary tract infections are one of the most common causes of acute sickness in infants and toddlers, affecting an estimated $8 \%$ of female and $2 \%$ of male, with a recurrence rate ranging from $10 \%$ to $30 \%{ }^{3}$

Canadian Pediatric Society has developed guidelines and recommendations for diagnosis of urinary 
tract infection, regarding sampling and urine testing and interpretation of results for treatment purposes. ${ }^{4}$ Infection of Urinary tract (UTI) in small kids frequently presents with vague symptoms and getting a urine sample from those who are severely ill is not easy. Because of non-specific symptoms, urinary tract infections are often missed in about half of young children on first consultation. ${ }^{5}$ Recent studies in United Kingdom suggest that up to $80 \%$ of urinary tract infections may not be diagnosed. Obtaining a sample of urine for culture in kids, who are acutely ill, should be of prime importance. ${ }^{6}$

The diagnosis may therefore be missed by primary consultant. ASB may lead to symptomatic infection. Whether symptomatic or not, urinary tract infection can cause kidney damage and scarring in young children. ${ }^{7}$ About one third of patients with asymptomatic infection have underlying urinary tract abnormalities like vesico-uerteric reflux. ${ }^{8}$ Renal scarring during early life has strong association with hypertension and chronic kidney disease in later life. ${ }^{9}$ However, timely and judicious treatment of urinary tract infection decreases the likelihood of renal injury and averts reduction in kidney functions. ${ }^{7}$

Symptoms are typically ambiguous and unclear and they aren't always related to the urinary tract. ${ }^{7}$ ASB may be followed by symptomatic UTI. Whether symptoms are present or not, renal damage and scarring occur in a number of patients especially if it occurs before five years of age. ${ }^{7}$

In resource-limited situation regular examination of urine is not carried out in well-looking children this leads to missed diagnosis of asymptomatic infection and compromises the advantage of timely treatment to prevent kidney damage. ${ }^{10}$ In one study, it was found that $10.6 \%$ cases of the 253 children had bacteriuria with no symptoms. The large number of isolates was E.coli $33.3 \%$, followed by Staphylococcus saphrophyticus $22.2 \%$ and Staphylococcus aureus $18.5 \% .^{11}$

\subsection{Research Objectives (RO)}

RO 1: to determine the prevalence of asymptomatic bacteriuria in children coming for routine immunization in District Peshawar, Pakistan.

RO 2: to determine the distribution of asymptomatic bacteriuria by sex in children coming for routine immunization in District Peshawar, Pakistan.

RO 3: to determine the distribution of asymptomatic bacteriuria by age groups in children coming for routine immunization in District Peshawar, Pakistan.

1.4 Significance: Studies on ASB are not done so far in our population with healthy children and it has been suggested above, that if left untreated it can lead to UTI which may ultimately lead to long term complications, especially in the urinary tract like scarring, renal insufficiency and hypertension. This research will provide us local burden of the disease.

\section{MATERIALS AND METHODS}

2.1 Design, settings, duration \& sampling: This cross-sectional study was carried out in Department of Pediatrics, Khyber Girls Medical College, Peshawar, Pakistan from March 2017 to August 2017. The study was carried out after endorsement from Institutional Ethical and Research Committee.

All children presenting to vaccination center for routine immunization were eligible. A sample of 146 children was selected from these children. Children with history of complicated urinary tract infection (UTI), including structural abnormalities, calculi, infected cysts, bladder dysfunction, detected on the basis of patient's previous medical record and history were excluded from the study. Also children on antibiotics or immuno-suppressant therapy were excluded.

2.3 Conduct of procedure: The parents of patient were told about the study's intent and benefits, and a written informed consent was obtained. A history and physical examination were performed on all patients. Two clean catch urine specimens two hours apart were obtained for all the children for analysis of ASB. All specimens were examined by the same laboratory and same consultant.

2.3 Data Collection Plan: Sex, age groups and age in years were three demographic, while presence of ASB was a single research variable. Sex and presence of ASB were nominal, age group ordinal and age in years was numeric variable. Sex, age groups and presence of ASB were analyzed by count and percentage with $80 \% \mathrm{Cl}$. Age in years was analyzed by mean, SD, minimum, maximum and range with $95 \% \mathrm{CL}$.

\section{RESULTS}

3.1 Sample description \& prevalence of ASB: Out of 146 children, 65 (44.52\%) were males and $81(55.48 \%)$ females, and 51 (34.93\%) were in age group $\leq 3$ years, $52(35.62 \%)$ in $3.0-6.50$ years and $43(29.45 \%)$ in $6.51-10$ years. The mean age of the sample was $4.82 \pm 2.81(09-9.50$, range 8.60$)(95 \% \mathrm{Cl}$ 4.36-5.28) years.

Out of 146 children, ASB was found in 16 (10.96\%) cases. (Table 3.1)

3.2 Distribution of 16 ASB patients by sex and age groups: Prevalence of ASB was higher $4.11 \%$ in boys than $6.856 \%$ girls. It was highest $6.85 \%$ in age group $3.0-6.50$ years, followed by $2.74 \%$ in $6.51-10$ years and $1.37 \%$ in age group $\leq 3.0$ years. (Table 3.2) 
Table 3.1: Prevalence of ASB in children of District Peshawar, Pakistan $(n=146)$

\begin{tabular}{|l|l|c|c|c|c|}
\hline \multirow{2}{*}{ Variable } & \multirow{2}{*}{ Attributes } & \multicolumn{2}{|c|}{ Sample Statistics } & \multicolumn{2}{c|}{$80 \%$ Cl for proportion of population } \\
\cline { 3 - 6 } & & Count & Percentage & Lower & Upper \\
\hline \multirow{2}{*}{$\begin{array}{l}\text { Presence of } \\
\text { ASB }\end{array}$} & Yes & 16 & 10.96 & 08.07 & 14.71 \\
\cline { 2 - 6 } & No & 130 & 89.04 & 85.28 & 91.93 \\
\hline Total & 146 & $100 \%$ & \multicolumn{2}{c|}{ Population Parameters } \\
\hline
\end{tabular}

Table 3.2: Distribution of 16 ASB children by sex and age groups of District Peshawar, Pakistan $(n=146)$

\begin{tabular}{|c|c|c|c|c|c|c|}
\hline \multirow{2}{*}{ Variables } & \multirow{2}{*}{ Attributes } & \multirow{2}{*}{$\begin{array}{c}\text { Sample } \\
\text { Size }\end{array}$} & \multicolumn{2}{|c|}{ Sample Statistics } & \multicolumn{2}{|c|}{$80 \% \mathrm{Cl}$ for proportion } \\
\hline & & & Count & Percentage & Lower & Upper \\
\hline \multirow{2}{*}{ Sex } & Males & 65 & 06 & $6 * 100 / 146=4.11$ & 02.46 & 06.77 \\
\hline & Females & 81 & 10 & $10 * 100 / 146=6.85$ & 04.62 & 10.03 \\
\hline \multirow{3}{*}{$\begin{array}{l}\text { Age groups } \\
\text { (years) }\end{array}$} & $\leq 3.0$ & 51 & 02 & $2 * 100 / 146=1.37$ & 00.57 & 03.25 \\
\hline & $3.0-6.50$ & 52 & 10 & $10 * 100 / 146=6.85$ & 04.62 & 10.03 \\
\hline & $6.51-12$ & 43 & 04 & $4 * 100 / 146=2.74$ & 01.46 & 05.06 \\
\hline \multirow{2}{*}{ ASB } & \multicolumn{2}{|c|}{ Yes } & 16 & $16 * 100 / 146=10.96$ & 08.07 & 14.71 \\
\hline & \multicolumn{2}{|c|}{ No } & 130 & $130 * 100 / 146=89.04$ & 85.28 & 91.93 \\
\hline \multicolumn{3}{|c|}{ Total } & 146 & $100 \%$ & \multicolumn{2}{|c|}{ Population parameters } \\
\hline
\end{tabular}

\section{DISCUSSION}

Out of 146 children, 65 (44.52\%) were males and 81 (55.48\%) females, and 51 (34.93\%) in age group $\leq 3$ years, $52(35.62 \%)$ in 3.0-6.50 years and $43(29.45 \%)$ in 6.51-10 years. Mean age of sample was $4.82 \pm 2.81$ (09-9.50, range 8.60$)(95 \% \mathrm{Cl} 4.36-5.28)$ years.

ASB was found in $16(10.96 \%)$ cases. Prevalence of ASB was higher $4.11 \%$ in boys than $6.856 \%$ girls. It was highest $6.85 \%$ in age group $3.0-6.50$ years, followed by $2.74 \%$ in $6.51-10$ years and $1.37 \%$ in age group $\leq 3.0$ years.

This has been the subject of many studies in the school-aged kids. ${ }^{12}$ When questioned closely many of these children will have symptoms of urinary infection, and many of them will have episodes of symptomatic infection. So screening for ASB becomes important for early detection of asymptomatic infection and identification of kidney abnormalities, which will help in prevention of serious infection and renal scarring. How frequently these infections cause renal damage or whether their timely treatment help prevent renal scarring, is not known. Screening of children at a particular age would be necessary, to prove that whether controlling infection prevent renal scarring. This would not be cost effective unless a more economic and simple screening test would be used, which would be accessible and affordable to the patients, family, school health workers and microbiologists.

A study conducted by Canadian Task Force identified ASB in $1.8 \%$ of girls and in insignificant number of male. ${ }^{13}$ Renal scarring, obstructed uropathy, hypertension and kidney insufficiency might be prevented by early detection and timely treatment of ASB. Approximately $10-35 \%$ of infants and toddlers with ASB have VUR and 6-37\% have kidney scarring or other abnormalities, whereas these findings are not common in general population. ${ }^{14}$ In the first year of life, the occurrence of ASB is more in boys (2.5\%) than girls $(0.9 \%)$, this is due to the fact that male has more anatomic abnormalities of the urinary tract than female. ${ }^{15}$

After the first year of life, girls have high incidence $(1-2 \%)$ than boys. ${ }^{6}$ In fewer than $10 \%$, the ASB leads to symptomatic urinary tract infection..$^{15}$ Sometimes the ASB may be a sign underlying urinary tract pathology. ${ }^{14}$ About $5-6 \%$ of female have experienced a minimum of one episode of bacteriuria during the period of their school and approximately $80 \%$ of children were reported to have recurrent infections. ${ }^{14}$

Jomezadeh, et al. reported a study done in Lahore, Pakistan declared that 27 (10.6\%) cases of the 253 
patients were found to ASB. A positive urine culture was found in 21 (12.8\%) of girls out 164 cases, while $6(6.7 \%)$ of 89 boys had convincing bacteriuria. The large number of isolate were E.Coli nine (33\%), while staph saprophyticus six $(22.2 \%)$ and staphylococcus aureus come next. The sensitivity test shows a high level of resistance to cefazolin, amoxicillin and co-trimoxazole. While most of isolate shows sensitivity to ofloxacin and cefixime. ${ }^{11}$

In growing children the prognosis may be poor, if neonatal bacteriuria occurs in the setting of underlying anatomical abnormalities. ${ }^{16}$

Although a large number of pathogens are associated with urinary tract infection. ${ }^{14}$ Enterobacteriaceae are usual the causative agent in first uncomplicated lower urinary tract infections. In healthy children, the incidence of urinary tract infection increases substantially with increasing age.

In premature neonates, prevalence of ASB is estimated to be about $3 \% .{ }^{15}$ Litaka, et al. screened 28,202 healthy school children for ASB; 14,575 males and 13,627 females, by dipstick and culture. The prevalence of ASB was $0.06 \%$ in male and $0.52 \%$ in female was observed. A high percentage of false negative results were obtained with dipstick method, while with dipslide method a high rate of false positive results were observed. Out of all the screened children, $60 \%$ continued to have bacteriuria for nine months; these children were then followed by monthly cultures. Nine out of 26 children with persistent bacteriuria were found to have urinary tract abnormalities. ${ }^{17}$

Lindberg recorded the outcome of 116 school kids with ASB who are treated and those who were no treated. Spontaneous resolution of bacteriuria was observed in $11 \%$ of untreated children within a year. In the treated population, a short course of oral nitrofurantoin cured the bacteriuria in $93 \%$ cases. In one year, $30 \%$ of patients who were abacteriuric spontaneously experienced bacteriuria recurrence. In $79 \%$ (19/24) the first recurrence occurred within three months. Within nine months, 19 of the 24 patients who had recurrences $(79 \%)$ had a third infection. ${ }^{18}$

In Europe, Nebigel, et al..$^{19}$ found $5.8 \%$ prevalence in toddlers, while Oner, et al. ${ }^{20}$ found $3.3 \%$ prevalence. In a study of toddlers in Calabar, Nigeria, Eyonget, al. ${ }^{21}$ discovered a prevalence of $5.6 \%$. In a study of toddlers in Nigeria, Jomboet, al. ${ }^{22}$ recorded an ASB incidence of $7.3 \%$. Unlikely as it might be, some authors have found significantly higher ASB prevalence rates than we have.

In India, Kondapaneniet, al. ${ }^{23}$ found that $16.5 \%$ out of 200 school children had ASB, while Salem, et al. ${ }^{24}$ found that $30 \%$ Egyptian children had ASB. In Nigeria, Iduoriyekemwenet, al. ${ }^{25}$ and Wogu. et al. ${ }^{8}$ both recorded $10.3 \%$ ASB rates in Benin City, and
Alo, et al. ${ }^{10}$ reported $48 \%$ in rural primary school children in Ebonyi State.

The high occurrence rate of ASB in the above mentioned researches can be explained by a number of facts. In a number of the researches the size of the sample was comparatively small. ${ }^{8,23-25}$ In some of the researches like; Iduoriyekemwen, et al. ${ }^{25} \mathrm{a}$ large proportion of infants were included in the study, who were known to have higher risk for developing UTI. The truth that Salem, et al. ${ }^{24}$ included kids with type 1 diabetes and the patients of Iduoriyekemwen, et al. ${ }^{25}$ were all HIV-infected, may be the reason for high prevalence of ASB found in these studies.

The high prevalence rate of ASB of $48 \%$ reported by Alo, et al. ${ }^{10}$ may be due to the reality that the research was conducted in a rural area, where level of personal hygiene and health consciousness is very low. The time between urine collection and its analysis is an important factor for false positive results. This may be a factor for high rates of ASB in some of these studies.

A school investigation found that the prevalence of ASB in boys under the age of one year was $0.66 \%$ and $0.30 \%$ respectively. For boys over the age of one year, the statistics were $0.08 \%(95 \% \mathrm{Cl}, 0.01$ $0.37)$ and $0.02 \%(95 \% \mathrm{Cl}, 0.00-0.06)$ respectively. In studies the prevalence of ASB in boys situated in countries with more than $90 \%$ rate of circumcision was significantly $p=0.04$ was lower than in countries with decreased ratios of circumcision $(0.10 \%$, $95 \% \mathrm{Cl} 0.01-0.51$ ) vs. $0.50 \%, 95 \% \mathrm{Cl} 0.20-0.93)$. The effect of this variable was independent of age. ASB was found in $0.47 \%$ and $0.38 \%$ females respectively. As compared to older girls, the prevalence of ASB was slightly $(p=.04)$ lower in girls under the age of two years $(0.22 \%, 95 \% \mathrm{Cl} 0.07-0.45)$ vs. $0.52 \%$, $95 \% \mathrm{Cl} 0.39-0.68){ }^{26}$

The clinical significance of ASB in patients goes way beyond its prevalence only. The possibility of kidney scarring as a result of ASB makes it a serious problem. Detailed workup revealed that a large number of affected patients had signs of kidney damage in one of the studies, where ASB rate was low. ${ }^{27}$

Jha, et al. conducted a study to screen children for bacteriura in different schools of Pokhara valley Nepal. Out of 502 samples, seven (1.39\%) samples grew the bacterial pathogens that are responsible to cause urinary tract infection. Among them Escherichia coli four $(57.14 \%)$ was the predominant bacterial pathogen. ${ }^{28}$

\section{CONCLUSION}

Asymptomatic bacteriuria is quite common in our children. It is a significant health risk especially among females, and we suggest more studies to find out the underlying factors and follow up studies on its complications. 


\section{REFERENCES}

1. Averbeck MA, Rantell A, Ford A, Kirschner-Hermanns R, Khullar V, Wagg A, et al. Current controversies in urinary tract infections: ICI-RS 2017. Neurourol Urodyn 2018 Jun;37(S4):S86-S92. https://doi.org/10.1002/nau.23563

2. Wullt B, Sundén F, Grabe M. Asymptomatic bacteriuria is harmless and even protective: Don't treat if you don't have a very specific reason. Eur Urol Focus 2019 Jan;5(1):15-6. https://doi. org/10.1016/j.euf.2018.07.004

3. Williams G, Craig JC. Prevention of recurrent urinary tract infection in children. Curr Opin Infect Dis 2009;22(1):72-6. https://doi.org/10.1097/ QCO.0b013e328320a885

4. Robinson JL, Finlay JC, Lang ME, Bortolussi R; Canadian Paediatric Society, Community Paediatrics Committee, Infectious Diseases and Immunization Committee. Urinary tract infection in infants and children: Diagnosis and management. Pediatrics Child Health 2014;19(6):315-9: https://doi.org/10.1093/ pch/19.6.315

5. Downing $\mathrm{H}$, Jones $\mathrm{E}$, Gal $\mathrm{M}$. The diagnosis of urinary tract infections in young children (DUTY): protocol for a diagnostic and prospective observational study to derive and validate a clinical algorithm for the diagnosis of UTI in children presenting to primary care with an acute illness. BMC Infect Dis 2012;12:158. https://doi. org/10.1186/1471-2334-12-158

6. Coulthard MG, Lambert HJ, Vernon SJ. Does prompt treatment of urinary tract infection in preschool children prevent renal scarring: mixed retrospective and prospective audits. Arch Dis Child 2013;99(4):342-7. https://doi.org/10.1136/ archdischild-2013-304428

7. Taneja N, Chatterjee SS, Singh M, Singh S, Sharma M. Pediatric urinary tract infections in a tertiary care center from North India. Indian J Med Res 2010;131:101-5.

8. Wogu MD, Ogbebor NE. Prevalence of asymptomatic bacteriuria in secondary school students in Benin City. Afr Res Rev 2011;5(4):145-51. https://doi.org/10.4314/afrrev.v5i4.69267

9. Park YS. Renal scar formation after urinary tract infection in children. Korean $\mathrm{J}$ Pediatr 2012;55(10):367-70. https://doi.org/10.3345/ kjp.2012.55.10.367

10. Alo M, Elom M, Anyim C, Okeh EN. Asymptomatic urinary tract infection among school children in rural area of Ebonyi State. Annals Bio Res 2012;3(5):2353-6.

11. Jomezadeh $\mathrm{N}$, Farajzadeh $\mathrm{A}$, Javaherizadeh $\mathrm{H}$, Torabizadeh $\mathrm{M}$. The prevalence of asymptomatic bacteriuria in infants and children. Pak Paed J 2011;35(1):13-6. https://doi.org/10.17257/ hufslr.2011.35.3.1

12. Davision JM, Sportt MS, Selkon JB. The effect of covert bacteriuria in school girls on renal function at 18 years and during pregnancy. Lancet 1984 Sep 22;324(8404):651-5. https:// doi.org/10.1016/S0140-6736(84)91222-4

13. Smith $\mathrm{MBH}$. Screening for urinary infection in asymptomatic infants and children. In: Canadian Task Force on the Periodic Health Examination. Canadian Guide to Clinical Preventive Health Care. Ottawa: Health Canada 1994;220-30.

14. Kunin CM. Detection, prevention and management of urinary tract infections. 4th ed. Philadelphia: Lea and Febiger; 1987.

15. American Academy of Pediatrics. Recommendation for pediatric preventive health care. Pediatrics 1995; 96:373-4.

16. Edelmann CM, Uguro JE, Fire BP, et al. Prevalence of Bacteriuria in full term and premature infants. J Pediatrics 1973 Jan;82(1):125-31. https://doi.org/10.1016/S0022-3476(73)80030-7

17. Litaka K, Sakai T, Oyama K, Izawa T, Igarashi S. Screening for bacteriuria in Japanese school children. Pediatr Int $1990 \mathrm{Dec} ; 32(6): 690-5$. https://doi.org/10.1111/j.1442-200X.1990. tb00906.x

18. Lindberg U. Asymptomatic bacteriuria in school girls. Acta Paediatrica 1975;64(5):718-24. https:// doi.org/10.1111/j.1651-2227.1975.tb03910.x

19. Nebigil I, Tumer N. Asymptomatic urinary tract infection in childhood. A J Med 1983;75:53-5.

20. Oner YA, Ahangari T, Artinyan E, Oz V, Kocazeybek B. A research on asymptomatic bacteriuria in 14 to 17-year-old female students. Urol Int 2004;73:325-8. https://doi. org/10.1159/000081593

21. Eyong KI, Anah MU, Udo JJ, Jombo GTA, Ewa AU, Etuk IS, et al. An evaluation of leukocyte esterase activity as a rapid screening test for significant bacteriuria in children. $\mathrm{J}$ Clin Med Res 2011;3(2):23-7.

22. Jombo GTA, Odey F, Ibor S, Bolarin DM, Ejezie GC, Egah DZ, et al. Subclinical significant bacteriuria among pre-school children in Calabar municipality: A survey. J Med Sci 2010; 1(4):134-40.

23. Kondapaneni SL, Surpam R, MohdAzaruddin, Devi G. Screening for asymptomatic bacteriuria in school -going children. Indian J Pub Health 2012;56(2):169-70. https://doi. org/10.4103/0019-557X.99925

24. Salem MA, Matter RM, Abdelmaksoud AA, El Masry SA. Prevalence of asymptomatic bacteriuria in Egyptian children and adolescents with type 1 diabetes mellitus. J Egypt Soc Parasitol 2009;39(3):951-62.

25. Iduoriyekemwen NJ, Sadoh WE, Sadoh AE. Asymptomatic bacteriuria in HIV positive Nigerian children. J Med Biomed Res 2012;11:88-94.

26. Shaikh N, Osio VA, Wessel CB, Jeong JH. Prevalence of asymptomatic bacteriuria in children: a meta-analysis. J Pediatr 2020 Feb;217:110-7. https://doi.org/10.1016/j.jpeds.2019.10.019 
27. Joseph TP, Streekumaran MI. Asymptomatic bacteriuria in school children. India $\mathrm{J}$ Pediatr 1989;56:121-3. https://doi.org/10.1007/ BF02749724
28. Jha BK, Singh YI. Prevalence of asymptomatic bacteriuria in children in Pokhara valley. Kathmandu Univ Med J 2007 Jan-Mar;5(1):81-4.

\section{CONFLICT OF INTEREST}

Authors declare no conflict of interest. GRANT SUPPORT AND FINANCIAL DISCLOSURE None declared.

\section{AUTHORS' CONTRIBUTION}

The following authors have made substantial contributions to the manuscript as under:

Conception or Design:

Acquisition, Analysis or Interpretation of Data:

Manuscript Writing \& Approval:

All the authors agree to be accountable for all aspects of the work in ensuring that questions related to the accuracy or integrity of any part of the work are appropriately investigated and resolved. 